Saudi Journal of Biomedical Research

Abbreviated Key Title: Saudi J Biomed Res ISSN 2518-3214 (Print) |ISSN 2518-3222 (Online)

\title{
Determination and Evaluation of Serum Lipid Profile, Creatinine and Glycated hemoglobin (HbA1c \%) in Sudanese Patients with Type 2 Diabetes Mellitus Associated with Obesity
}

\author{
Hani M. Mohamed ${ }^{1}$, Abdelgadir Eltom² ${ }^{2 *}$ Ahmed L. Osman ${ }^{2}$
}

${ }^{1}$ Department of Clinical Chemistry, College of Medical Laboratories Science, University for Sciences and Technology, Omdurman, Sudan ${ }^{2}$ Department of Medical Laboratory Sciences, College of Health Sciences, Gulf Medical University, Ajman, UAE

\begin{tabular}{|c|c|}
\hline DOI: 10.36348/SJBR.2019.v04i09.004 & \begin{tabular}{|l|l|l|} 
Received: 01.10.2019| Accepted: 08.10.2019 & Published: 17.10.2019
\end{tabular} \\
\hline
\end{tabular}

*Corresponding author: Abdelgadir Eltom

\section{Abstract}

A cross sectional study conducted during the period from February 2011 to April 2012 to determine and to evaluate the serum levels lipid profile, creatinine and $\mathrm{HbA}_{1 \mathrm{c}}$ in Sudanese patients with type 2 diabetes mellitus associated with obesity. Two hundred Sudanese with type 2 diabetes mellitus associated with obesity were selected as a test group from Khartoum, Omdurman and Khartoum North hospitals in Khartoum state, Sudan. The test group was compared with a control group, which included 100 apparently healthy volunteers. Blood specimens were collected from both groups, and the serum levels of lipid profile (total cholesterol, triglycerides, high density lipoprotein cholesterol $\left(\mathrm{HDL}_{\mathrm{C}}\right)$ and lowdensity lipoprotein cholesterol $\left(\mathrm{LDL}_{\mathrm{C}}\right)$, in addition to fasting plasma glucose (FPG) and creatinine and glycated hemoglobin $\left(\mathrm{HBA}_{1 \mathrm{C}}\right)$ were determined. Age and gender of the test group were matched with the control group. The serum levels of plasma glucose, total cholesterol, $\mathrm{HDL}_{\mathrm{C}}, \mathrm{LDL}_{\mathrm{C}}$, triglycerides, creatinine and $\mathrm{Hba}_{1 \mathrm{C}}$ were measured using spectrophotometer methods. Statistical Package for Social Science (SPSS version 11.5) computer software was used for data analysis. The results of this study indicated significantly raised means of the serum levels of total cholesterol, $\mathrm{LDL}_{\mathrm{C}}$ triglycerides and creatinine of the test group when compared with the control group, whereas the mean of the serum levels of $\mathrm{HDL}_{\mathrm{C}}$ of the test group showed a significant reduction when compared with the control group. The results of this study also indicates a significant elevation of the means of the serum levels of total cholesterol, LDL $_{C}$, triglycerides and creatinine among diabetic patients with ischemic heart disease when compared with those without ischemic heart disease, whereas the mean of the serum levels of $\mathrm{HDL}_{\mathrm{C}}$ among diabetic patients with ischemic heart disease shows a significant reduction when compared with those without ischemic heart disease. The means of the serum levels of total cholesterol, $\mathrm{LDL}_{\mathrm{C}}$, triglycerides and creatinine among diabetic patients with hypertension or having renal insufficiency were significantly raised when compared with those without these diseases. Whereas the means of the serum levels of $\mathrm{HDL}_{\mathrm{C}}$ among diabetic patients with hypertension or having renal insufficiency were found to be significantly decreased when compared with those without these diseases. The results of the current study shows a significant moderate positive correlation between the duration of diabetes (in years) and the serum levels of total cholesterol, $\mathrm{LDL}_{\mathrm{C}}$, triglycerides and creatinine, whereas there is a significant moderate negative correlation between the duration of diabetes (in years) and the serum levels of $\mathrm{HDL}_{\mathrm{C}}$, and shows a significant strong positive correlation between the duration of diabetes and the serum levels of creatinine. This study shows insignificant weak positive correlations between $\mathrm{Hba}_{1 \mathrm{C}}$ and the serum levels of total cholesterol, $\mathrm{LDL}_{\mathrm{C}}$, triglycerides and creatinine and insignificant weak negative correlation between $\mathrm{Hba}_{1 \mathrm{C}}$ and the serum levels of $\mathrm{HDL}_{\mathrm{C}}$. Conclusion: The serum levels of total cholesterol, triglycerides and LDL are significantly raised in obese - diabetic patients, whereas the levels of HDL are significantly reduced, so regular measurements of the serum levels of total cholesterol, $\mathrm{LDL}_{\mathrm{C}}$, triglycerides and creatinine and $\mathrm{Hba}_{1 \mathrm{C}}$ can be used as prognostic markers for follow up of obese - diabetic patients especially in those with complications such as hypertension, ischemic heart disease and renal insufficiency.

Keywords: Determination and Evaluation, Glycated hemoglobin, Blood specimens.

Copyright @ 2019: This is an open-access article distributed under the terms of the Creative Commons Attribution license which permits unrestricted use, distribution, and reproduction in any medium for non-commercial use (NonCommercial, or CC-BY-NC) provided the original author and source are credited.

\section{INTRODUCTION}

Obesity and diabetes are reaching epidemic proportions in developed countries in the $21^{\text {st }}$ century while, at the same time, they are also becoming disturbingly more prevalent in developing countries. Diabetes, the most common non-communicable disease, 
is having an increasing impact on rates of morbidity and mortality in Sudan. The spread of sedentary lifestyles and adoption of western dietary habits - high in refined carbohydrates and fat- are driving an increase in the number of people with obesity-related type 2 diabetes [1].

Diabetes mellitus is a group of metabolic disorders of carbohydrate metabolism in which glucose is underutilized, producing hyperglycemia. Some individual may experience acute life - threatening hyperglycemic episodes, such as ketoacidosis or hyperosmolar coma [2].

The new classification system identifies four types of diabetes mellitus: type 1, type 2, other specific types and gestational diabetes. Each of the type of diabetes mellitus identified extends across a clinical continuum of hyperglycemia and insulin requirements [3].

Patients with Type 2 diabetes are frequently affected by atherosclerotic vascular disease. These patients often have abnormalities of both quantity and quality of lipoproteins that, among other factors, might be responsible for the increased incidence of vascular complications. Several studies were conducted to find out the lipid abnormalities in diabetes mellitus and to ascertain the effect of anti-diabetic treatment on these abnormalities [4].

The prevalence of type 2 diabetes has escalated in recent years, mainly as a result of changes in lifestyle and increasing obesity. Death is usually due to cardiovascular disease, especially if nephropathy is already present in type 2 diabetes, hypertension is frequent co-morbidity, often being present when diabetes is diagnosed [5].

Data about the prevalence of diabetes epidemic in Sudan is limited. The most recent data come from a small-scale study that was carried out in 1996. The results of the study indicated a prevalence of $3.4 \%$ [4]. Overweight and obesity have reached epidemic proportions globally along with an adoption of a westernized lifestyle characterized by a combination of excessive food intake and inadequate physical activity. In the United States, the prevalence of obesity doubled during the past two decades, and currently $30 \%$ of the US adult population is classified as obese. An additional $35 \%$ of US adults are overweight but not obese. Children and adolescents are not immune to the epidemic. Among US children and adolescents, $16 \%$ are overweight and an additional 15\% are at risk of overweight. It has been estimated that the total number of adults with diabetes (mainly type 2 diabetes) will approximately double between 2000 and 2030, from 171 million to 366 million [6].
Obesity represents a major component of the metabolic syndrome and has a significant association with insulin resistance. Clearly, most individuals with the metabolic syndrome are overweight or frankly obese, and most people with insulin resistance have truncal obesity. It is this truncal, central, visceral, or predominately upper body distribution of body fat that has a stronger association for cardiovascular disease than only being overweight or having an increased body mass index (BMI) [7].

Although skeletal muscle is one of the major target organs of insulin, to our knowledge, no prospective study has investigated the association between total skeletal muscle mass and type 2 diabetes. The level of serum creatinine is used as a marker of renal function; it is elevated in patients with renal impairment. One of the serious complications of diabetes mellitus is diabetic nephropathy which is characterized by progressive deterioration of renal function that associated with reduction of creatinine clearance [8]. Glycated hemoglobin (glycosylated hemoglobin, hemoglobin $\mathrm{A}_{1 \mathrm{C}}$ ), is a form of hemoglobin used primarily to identify the average plasma glucose concentration over prolonged periods of time. It is formed in a non-enzymatic pathway by hemoglobin's exposure to high plasma levels of glucose [9]. The measurement of glycosylated hemoglobin $(\mathrm{GHb})$ is one of the well-established means of monitoring glycemic control in patients with diabetes mellitus [10]. Considering this hypothesis, in this study we examined the serum lipid profile, serum creatinine \& glycosylated hemoglobin (HbA1C) in type 2 diabetes Sudanese patient associated with obesity

\section{OBJECTIVES}

\section{General Objective}

- To determine and to evaluate the serum lipid profile, creatinine, HbA1c in obese Sudanese patient with type 2 diabetes mellitus in comparison to healthy subjects (non- diabetic non- obese) as a control group.

\section{Specific Objectives}

- To measure the serum levels of total cholesterol, triglyceride, high density lipoprotein (HDL), and low-Density lipoprotein (LDL), serum creatinine and Glycated hemoglobin in Sudanese patient with type 2 diabetes mellitus associate with obesity.

- To assess correlation between the serum levels of total cholesterol, triglyceride, high density lipoprotein (HDL), and low-density lipoprotein (LDL), and creatinine, with both; the duration of diabetes and the glycated hemoglobin $\%$.

\section{Hypothesis}

Obesity in addition to diabetes seems to increase the risk and prevalence of complication of diabetes. 


\section{MATERIALS AND METHODS}

\section{Study Approach and Design}

- This is a quantitative analytical, crosssectional and hospital- based study.

\section{Study Area and Period}

- The study was done in Khartoum state in different hospitals (Khartoum, Omdurman and Khartoum North hospitals) during the period from February 2011 to April 2012.

\section{Study Population and Sample Size}

The study was conducted on Sudanese patients with diabetes mellitus associated with obesity as test group $(n=200)$ and apparently healthy subjects (non diabetic, non-obese) as a control group, $(\mathrm{n}=100)$.

\section{Inclusion Criteria}

Test group: Sudanese patients with type 2 diabetes mellitus associated with obesity.

Control group: Apparently healthy subjects (nondiabetes, non- obese).

\section{Exclusion Criteria}

Patients with history of diabetes mellitus type1, liver disease, pancreatic disease, familial hyperlipidemia, or using drugs (B blockers, diuretics, and birth control pills) had been excluded.

\section{Ethical Considerations}

The objectivities of the study were explained to all individuals, participating in this study A written consent was obtained from each participant in this study.

\section{Data Collection and Clinical Assessment Interview and a Questionnaire}

LDL cholesterol= total cholesterol - HDL-triglycerides
Interview with the subjects were done to obtain the data. A questionnaire was specifically designed to obtain information which helps in either including or excluding certain individuals in or from the study respectively.

\section{Blood Sampling, Instruments and Reagents Used}

After a written consent and use of local antiseptic for the skin (70\% ethanol), a fasting sample of venous blood ( $3 \mathrm{mls}$ ) was collecte from each individual included in the study, from the arm directly in a centrifuge tube for serum preparation. Serum levels of total cholesterol, triglyceride, low density, high density lipoproteins and creatinine were measured by using a spectrophotometer BTS-J5 and reagents from Spin react company and by Biosystem reagent company to measure the Hemoglobin $\mathrm{A}_{1 \mathrm{C}}$. The method used were selected because.

All reagents are available in Sudan, easy to perform, specific and sensitive method.

\section{Measurement of Serum Total Cholesterol, Triglyceride \\ Enzymatic-spectrophotometric method [11, 12].}

\section{Measurement of Serum High Density Lipoproteins (HDL) Cholesterol Principle}

Very low density lipoproteins (VLDL) and low density lipoproteins (LDL) in the sample precipitate with phosphotungestate and magnesium ions. The supernatant contains high density lipoproteins (HDL). The HDL cholesterol is then spectrophotometrically measured by means of the coupled reactions [13].

\section{Serum low density lipoproteins (LDL) cholesterol}

Is calculated from Friede wald equation as fallows.

[14].

\section{Determination of Body Mass Index}

Body mass index was calculated from the formula. BMI = weight in kilograms / square of height in meters [15].

\section{Measurement of Serum Creatinine}

Kinetic-spectrophotometric alkaline picrate [16].

\section{Measurement of Hemoglobin $\mathrm{A}_{1 \mathrm{C}}$ Principle}

After preparation of the hemolysate, where the labile fraction is eliminated, hemoglobin's were retained by a cationic exchange resin. Hemoglobin $\mathrm{A}_{1 \mathrm{C}}\left(\mathrm{Hb} \mathrm{A}_{1 \mathrm{C}}\right)$ is specifically eluted after washing away the hemoglobin $\mathrm{A}_{1 \mathrm{a}}+\mathrm{b}$ fraction $\left(\mathrm{Hb} \mathrm{A}_{1 \mathrm{a}+\mathrm{b}}\right)$, and is quantified by direct photometric reading at $415 \mathrm{~nm}$ [17].

\section{Quality Control}

The precision and accuracy of all methods used in this study were cheeked each time a batch was analyzed by including commercially prepared control sera.

\section{Statistical Analysis}

The data collected in this study were analyzed using SPSS computer program. The means and the standard deviations of the serum levels of total cholesterol, triglycerides, HDL-C and LDL-C, creatinine and $\mathrm{HbA}_{1 \mathrm{c}}$ were calculated and the independent $\mathrm{t}$ test was used for comparison.

Linear regression analysis was used to assess correlations between the body mass index (BMI), 
$\mathrm{HbA}_{1 \mathrm{c}} \%$, the duration of diabetes and the serum levels of triglycerides, total cholesterol, HDL-C, LDL-C, and creatinine.

\section{RESULTS}

This study was conducted on 200 patients with type 2 diabetes as a test group and 100 apparently healthy (non- diabetic) volunteers as a control group. Age and gender of the test group were matched with the control group.
In this study the test group was composed of 112 males (56\%), and 88 females (44\%), whereas the control group was composed of 59 males $(59 \%)$, and 41 females $(41 \%) .33 .5 \%(n=67)$ of the diabetic patients were hypertensive, $14 \%(\mathrm{n}=29)$ have ischemic heart disease, $14 \% \quad(n=28)$ have renal insufficiency, all diabetic patients included in this study were described as obese according to BMI calculations.

Table-1: Baseline characteristics of the test group and the control group

\begin{tabular}{|l|l|l|l|}
\hline Variable & $\begin{array}{l}\text { Test group } \\
\mathbf{n = 2 0 0}\end{array}$ & $\begin{array}{l}\text { Control group } \\
\mathbf{n = 1 0 0}\end{array}$ & P. value \\
\hline Age (years) & $\begin{array}{l}60.72 \pm 9.18 \\
(41-85)\end{array}$ & $\begin{array}{l}59.75 \pm 12.36 \\
(40-84)\end{array}$ & 0.489 \\
\hline Weight $(\mathrm{Kg})$ & $\begin{array}{l}77.30 \pm 14.85 \\
(51-101)\end{array}$ & $\begin{array}{l}69.89 \pm 14.33 \\
(47-98)\end{array}$ & 0.013 \\
\hline Height $(\mathrm{Cm})$ & $164.86 \pm 13.18$ & $\begin{array}{l}162.20 \pm 14.50 \\
(137-185)\end{array}$ & 0.068 \\
& $(140-190)$ & $\begin{array}{l} \\
(18.86 \pm 3.91\end{array}$ & 0.005 \\
\hline BMI $\left(\mathrm{Kg} / \mathrm{m}^{2}\right)$ & $32.92 \pm 5.29$ & $29.2)$ & \\
& $(30.1-36.4)$ & & \\
\hline
\end{tabular}

- The table shows the mean \pm Std. deviation, range in brackets and probability $(\mathrm{P})$.

- $\mathrm{t}$ - test was used for comparison.

- $\quad \mathrm{P}$ - Value $\leq 0.05$ is considered significant.

Table-2: Comparison of means of serum levels of T. cholesterol, HDLc, LDLc, triglycerides and creatinine of the test group and the control group

\begin{tabular}{|l|l|l|l|}
\hline Variable & $\begin{array}{l}\text { Test group } \\
\mathbf{n = 2 0 0}\end{array}$ & $\begin{array}{l}\text { Control group } \\
\mathbf{n = 1 0 0}\end{array}$ & P value \\
\hline s.t.cholesterol(mg/dL) & $\begin{array}{l}190.24 \pm 30.53 \\
(150-260)\end{array}$ & $\begin{array}{l}164.63 \pm 13.37 \\
(140-199)\end{array}$ & 0.000 \\
\hline S. HDLc(mg/dL) & $\begin{array}{l}40.30 \pm 10.099 \\
(27-65)\end{array}$ & $\begin{array}{l}53.95 \pm 8.170 \\
(40-74)\end{array}$ & 0.021 \\
\hline S. LDLc(mg/dL) & $\begin{array}{l}122.37 \pm 39.39 \\
(70-180)\end{array}$ & $\begin{array}{l}95.06 \pm 13.14 \\
(70-125)\end{array}$ & 0.013 \\
\hline S.Triglycerides(mg/dL) & $\begin{array}{l}138.68 \pm 40.851 \\
(80-225)\end{array}$ & $\begin{array}{l}100.28 \pm 24.869 \\
(60-150)\end{array}$ & 0.020 \\
\hline S. Creatinine(mg/dL) & $\begin{array}{l}1.07 \pm 0.29 \\
(0.6-1.5)\end{array}$ & $\begin{array}{l}0.77 \pm 0.14 \\
(0.5-1.0)\end{array}$ & 0.032 \\
\hline
\end{tabular}

- The table shows the mean \pm SD deviation and range in brackets and probability (P value)

- t-test was used for comparison

- $\quad \mathrm{P}$-value $\leq 0.05$ is considered significant.

Table-3: Comparison of means of serum levels of T. cholesterol, HDLc, LDLc, triglycerides and creatinine of the diabetic patients with ischemic heart disease and those without ischemic heart disease.

\begin{tabular}{|l|l|l|l|}
\hline Variable & $\begin{array}{l}\text { Patients with ischemic heart disease } \\
\mathbf{n = 2 9}\end{array}$ & $\begin{array}{l}\text { Patients without ischemic } \\
\text { heart disease } \\
\text { n=171 }\end{array}$ & P value \\
\hline S.total cholesterol $(\mathrm{mg} / \mathrm{dL})$ & $231.07 \pm 13.72$ & $183.31 \pm 38.68$ & 0.000 \\
\hline S.HDLc $(\mathrm{mg} / \mathrm{dL})$ & $29.38 \pm 2.62$ & $42.15 \pm 9.72$ & 0.000 \\
\hline S.LDL c $(\mathrm{mg} / \mathrm{dL})$ & $160.45 \pm 10.47$ & $115.91 \pm 26.53$ & 0.007 \\
\hline S.Triglycerides mg/dL) & $164.28 \pm 16.13$ & $130.94 \pm 36.68$ & 0.016 \\
\hline S.Creatinine (mg/dL) & $1.42 \pm 0.13$ & $1.010 \pm 0.27$ & 0.025 \\
\hline
\end{tabular}

- The table shows the mean $\pm \mathrm{SD}$ deviation and probability (P value)

- $\quad \mathrm{t}$-test was used for comparison 
- $\quad \mathrm{P}$-value $\leq 0.05$ is considered significant.

Table-4: Comparison of means of serum levels of T. cholesterol, HDLc, LDLc, triglycerides and creatinine of the diabetic patients with hypertension with those without hypertension

\begin{tabular}{|l|l|l|l|}
\hline Variable & $\begin{array}{l}\text { Patients with hypertension } \\
\mathbf{n = 6 7}\end{array}$ & $\begin{array}{l}\text { Patients without hypertension } \\
\mathbf{n = 1 3 3}\end{array}$ & P value \\
\hline S.total cholesterol (mg/dL) & $229.52 \pm 9.45$ & $170.44 \pm 13.51$ & 0.000 \\
\hline S.HDLc (mg/dL) & $28.82 \pm 0.98$ & $46.08 \pm 7.27$ & 0.006 \\
\hline S.LDL c (mg/dL) & $159.81 \pm 6.19$ & $103.50 \pm 14.59$ & 0.000 \\
\hline S.Triglycerides (mg/dL) & $183.43 \pm 15.39$ & $116.13 \pm 29.47$ & 0.000 \\
\hline S.Creatinine (mg/dL) & $1.42 \pm 0.08$ & $0.89 \pm 0.19$ & 0.000 \\
\hline
\end{tabular}

- The table shows the mean $\pm \mathrm{SD}$ deviation and probability (P value)

- t-test was used for comparison

- P-value $\leq 0.05$ is considered significant.

Table-5: Comparison of means of serum levels of T. cholesterol, HDLc, LDLc, triglycerides and creatinine of the diabetic patients with renal insufficiency with those without renal insufficiency

\begin{tabular}{|l|l|l|l|}
\hline Variable & $\begin{array}{l}\text { Patients with renal insufficiency } \\
\mathbf{n = 2 8}\end{array}$ & $\begin{array}{l}\text { Patients without renal insufficiency } \\
\mathbf{n = 1 7 2}\end{array}$ & P value \\
\hline S.total cholesterol (mg/dL) & $232.89 \pm 13.72$ & $183.29 \pm 26.62$ & 0.011 \\
\hline S.HDLc (mg/dL) & $29.82 \pm 5.21$ & $42.00 \pm 9.67$ & 0.010 \\
\hline S.LDL c (mg/dL) & $160.36 \pm 11.79$ & $116.18 \pm 26.61$ & 0.015 \\
\hline S.Triglycerides (mg/dL) & $183.29 \pm 19.92$ & $131.41 \pm 38.74$ & 0.006 \\
\hline S.Creatinine (mg/dL) & $1.45 \pm 0.13$ & $1.01 \pm 0.27$ & 0.000 \\
\hline
\end{tabular}

- The table shows the mean \pm SD deviation and probability ( $\mathrm{P}$ value)

- $\quad t$-test was used for comparison

- $\quad$-value $\leq 0.05$ is considered significant.

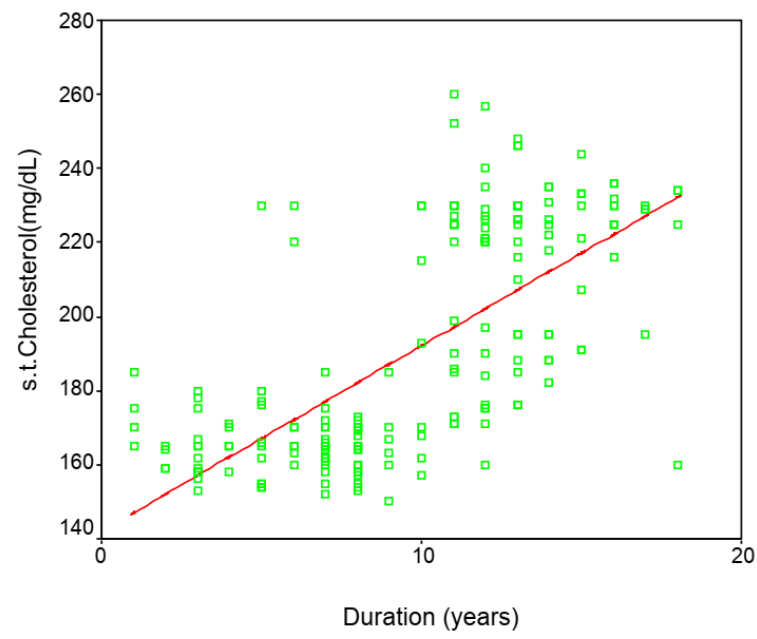

Fig-1: The relationship between the serum levels of T.cholesterol $(\mathrm{mg} / \mathrm{dL})$ and the duration of diabetes $(r=0.69$, $\mathbf{P}=\mathbf{0 . 0 2 9}$ )

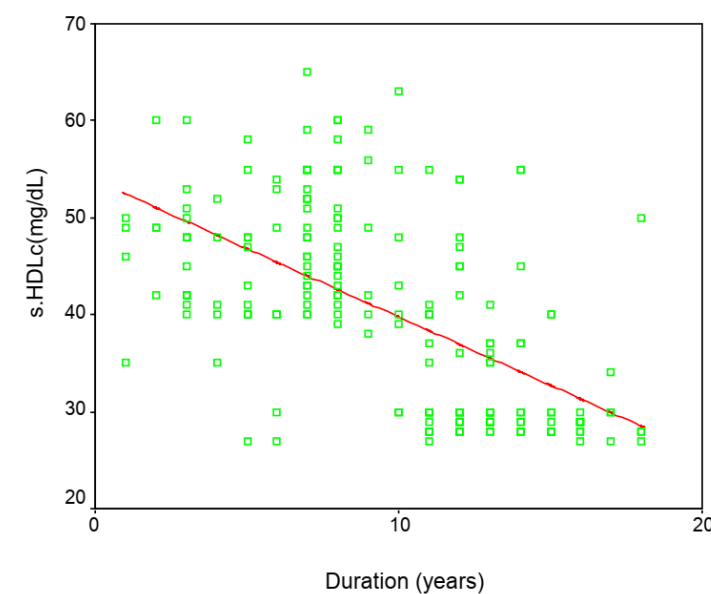

Fig-2: The relationship between the serum levels of HDLc $(\mathrm{mg} / \mathrm{dL})$ and the duration of diabetes $(\mathrm{r}=-\mathbf{0 . 5 9}, \mathrm{P}=\mathbf{0 . 0 4 3})$

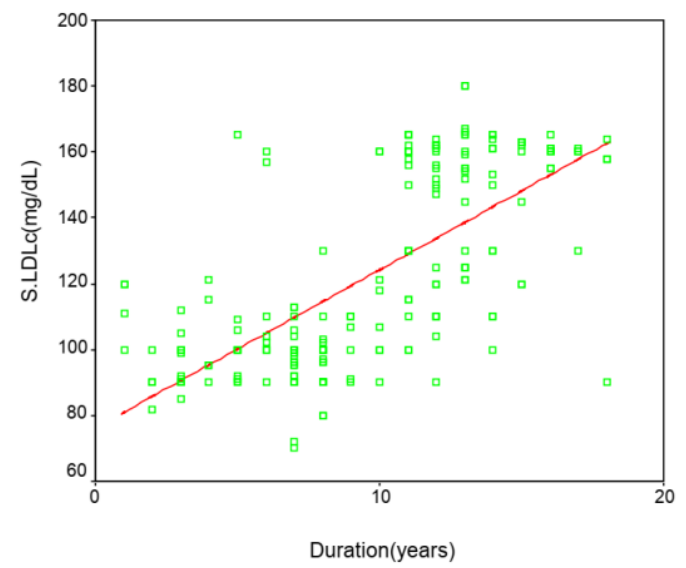

Fig-3: The relationship between the serum levels of LDLc $(\mathrm{mg} / \mathrm{dL})$ and the duration of diabetes $(\mathrm{r}=0.69, \mathrm{P}=0.022)$ 


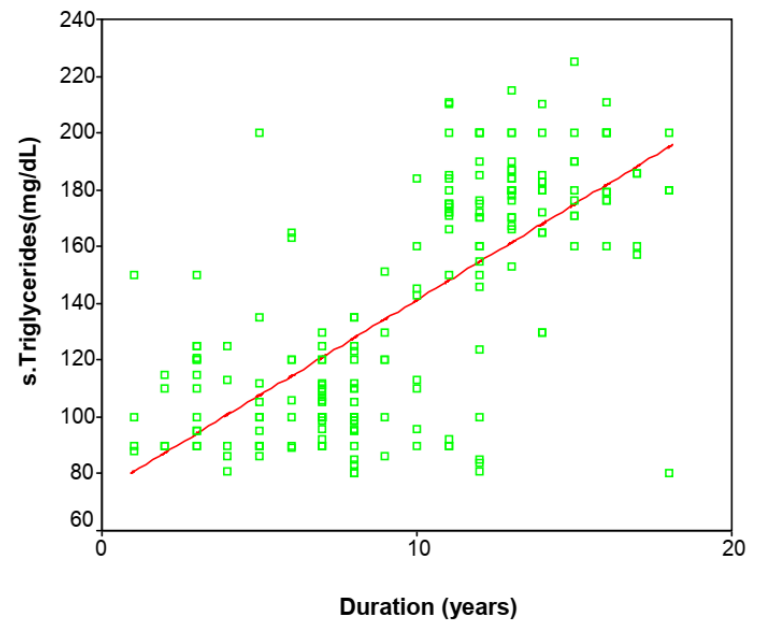

Fig-4: The relationship between the serum levels of triglycerides $(\mathrm{mg} / \mathrm{dL})$ and the duration of diabetes $(\mathrm{r}=0.69, \mathbf{P}=\mathbf{0 . 0 1 0})$

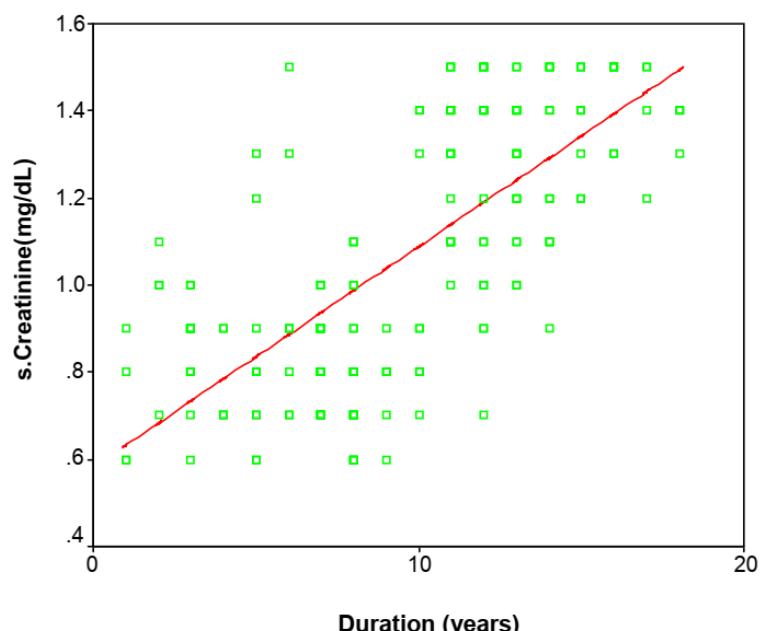

Fig-5: The relationship between the serum levels of creatinine $(\mathrm{mg} / \mathrm{dL})$ and the duration of diabetes $(\mathrm{r}=0.72, \mathrm{P}=0.000)$

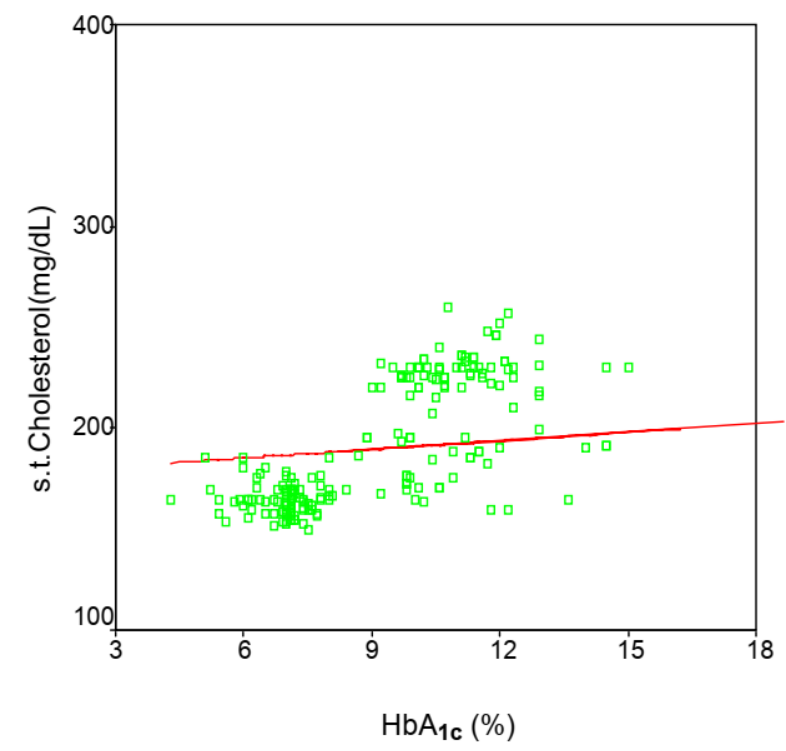

Fig-6: The relationship between the serum levels of T.Cholesterol $(\mathrm{mg} / \mathrm{dL})$ and $\mathrm{HbA}_{1 \mathrm{C}}(\mathrm{r}=0.32, \mathrm{P}=0.083)$

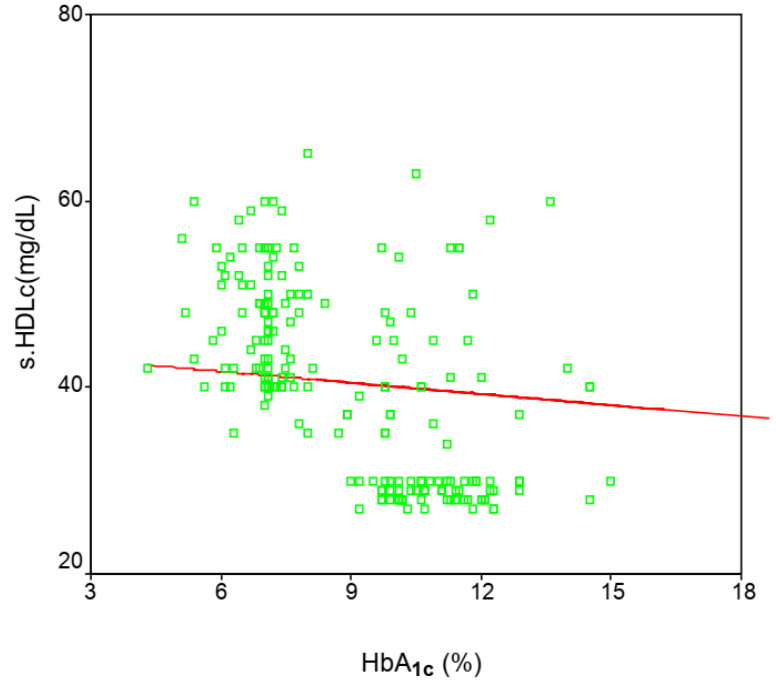

Fig-7: The relationship between the serum levels of HDLc $(\mathrm{mg} / \mathrm{dL})$ and $\mathrm{HbA}_{1 \mathrm{C}}(\mathrm{r}=-\mathbf{0 . 2 7}, \mathrm{P}=0.089)$

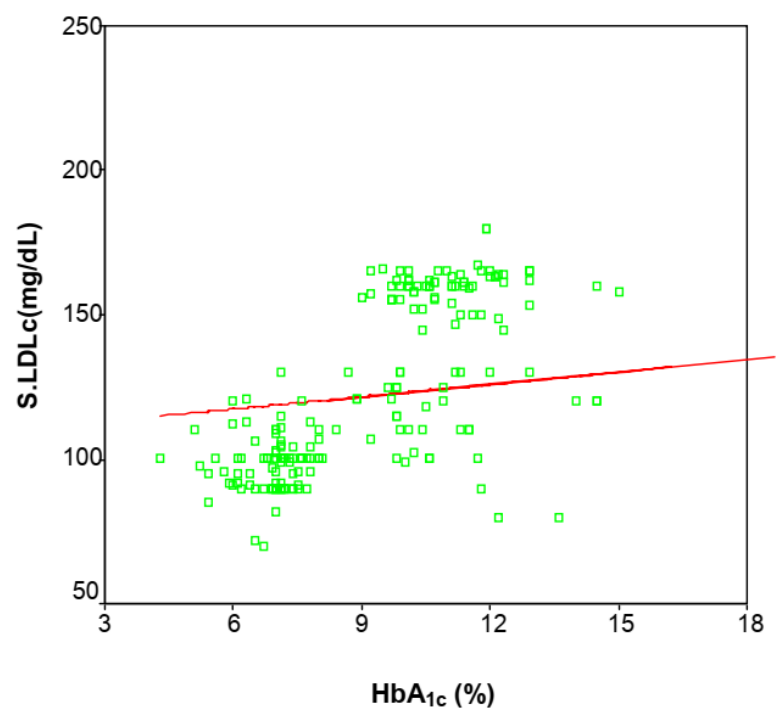

Fig-8: The relationship between the serum levels of LDLc $(\mathrm{mg} / \mathrm{dL})$ and $\mathrm{HbA}_{1 \mathrm{C}}(\mathrm{r}=0.32, \mathrm{P}=0.117)$

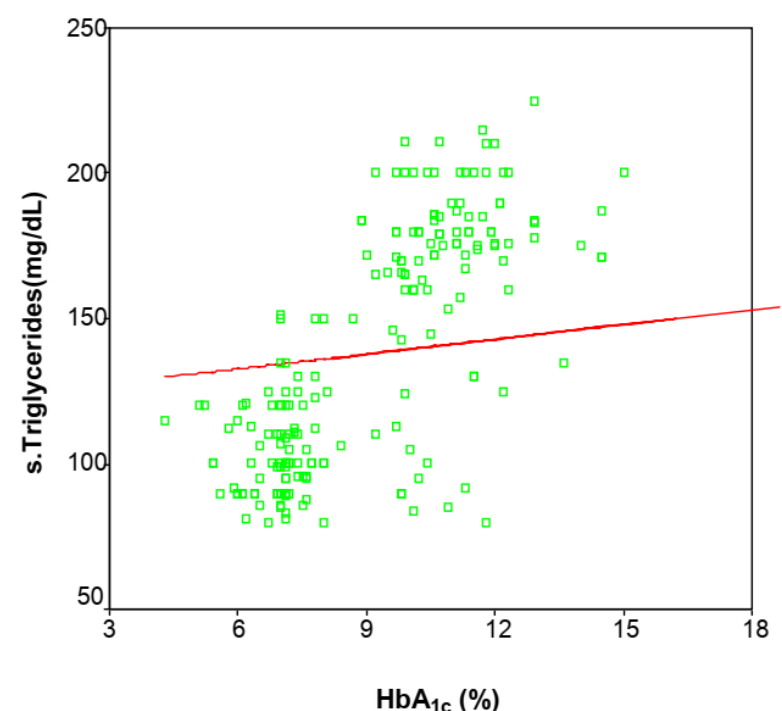

Fig-9: The relationship between the serum levels of Triglycerides $(\mathrm{mg} / \mathrm{dL})$ and $\mathrm{HbA}_{1 \mathrm{C}}(\mathrm{r}=0.28, \mathrm{P}=\mathbf{0 . 0 8 2})$ 


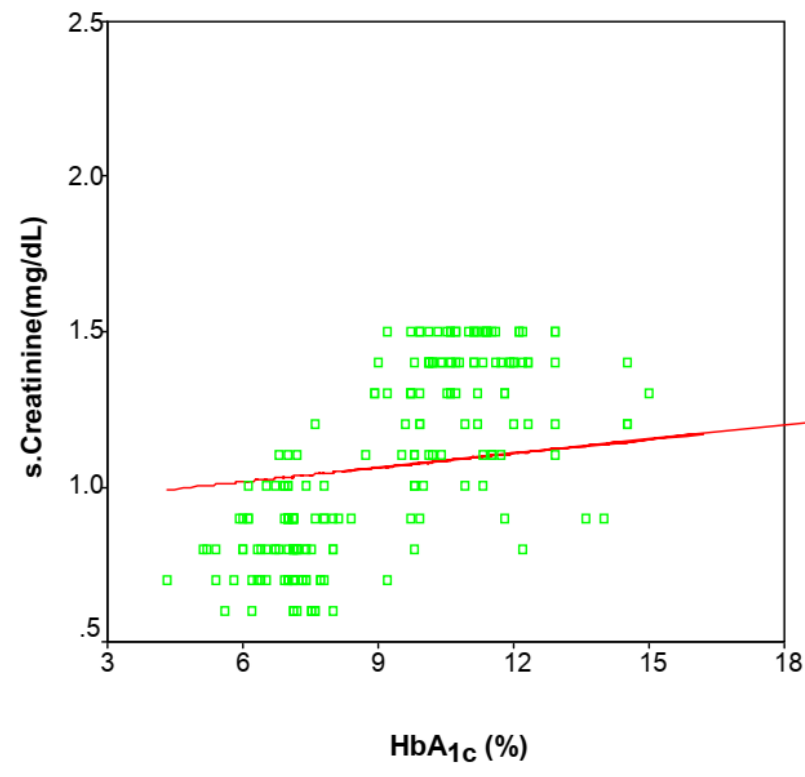

Fig-10: The relationship between the serum levels of Creatinine $(\mathrm{mg} / \mathrm{dL})$ and $\mathrm{HbA}_{1 \mathrm{C}}(\mathrm{r}=0.35, \mathrm{P}=0.061)$

\section{DISCUSSION}

Type 2 diabetes mellitus is the most common form of diabetes. It is characterized by disorders of insulin action and insulin secretion [15], and constitutes the majority of the diabetes cases. However, these patients are at an increased risk of developing macro vascular and micro vascular complications [27]. Cardiovascular diseases (CVD) are the main cause of increased mortality in patients with diabetes, and remains the leading cause of death in patients with diabetes mellitus, accounting for $50 \%$ of all deaths [27].

Damage of endothelial wall plays the key role in the development of diabetic complications. Hyperglycemia, oxidative stress, genetic factors, disturbances of lipid metabolism, hypertension, obesity, smoking, sedentary lifestyle and various growth factors are among the major causes of chronic diabetic complications [18].

In this study a test group of 200 patients with type 2 diabetes mellitus associated with obesity (as a test group) were compared to 100 apparently healthy (non-diabetic, non-obese) volunteers, both group were matched for age and gender. Weight and body mass index were significantly raised in patients with type 2 diabetes associated with obesity compared to controls, and according to BMI calculation all of the patients were described as obese $\left(\mathrm{BMI}>30 \mathrm{~kg} / \mathrm{m}^{2}\right)$.

In the present study, $33.5 \%$ of the test groups were hypertensive, $14 \%$ have ischemic heart disease, and $14 \%$ have renal insufficiency.

The current study showed a significant elevation of the means of the serum levels of total cholesterol of the test group when compared with the control group $(p=0.000)$, this agrees with the result of
Idogun et al., in a study done in Nigeria [19]. Dyslipidemia is a known risk factor for coronary atherosclerosis [20]. According to George et al., who reported a two to three time higher risk for coronary heart disease rate in diabetic patients with lipid abnormalities [21], this agrees with a study done by Taskinem, who reported that the mean of the serum level of total cholesterol was significantly higher in diabetic patients than in healthy control subjects $(\mathrm{p}=0.001)$ [21]. The present study also shows a significant difference between the means of the serum levels of total cholesterol of the diabetic patients with ischemic heart disease when compared with those without ischemic heart disease $(\mathrm{p}=0.000)$, this is because most of Sudanese diabetic patients are badly controlled [22].

The serum levels of total cholesterol of the diabetic patients with hypertension shows a significant elevation when compared with those with normal blood pressure $(\mathrm{P}=0.000)$, this agrees with the studies done by Albrki et al., [23], and Emile et al., [24], who found significantly increased levels of total cholesterol among diabetics with hypertension, and disagrees with that reported by Yaron et al., [25], who found no significant difference in the serum levels of total cholesterol among diabetic patients with hypertension when compared to diabetic non-hypertensive $(\mathrm{p}=0.456)$ [26].

The present study also shows a significant difference between the means of the serum levels of total cholesterol of the diabetic patients with renal insufficiency when compared with those who have normal renal functions $(\mathrm{P}=0.011)$, this is because renal insufficiency is associated with disturbance in lipid metabolism as reported by Ruderman \& Haudenschild [25].

The current study shows a significant moderate positive correlation between the serum levels of total cholesterol $(\mathrm{mg} / \mathrm{dL})$ and the duration of diabetes (in year) $(\mathrm{r}=0.69, \mathrm{P}=0.029)$, this agrees with that reported by Jones et al., [27], who found a significant moderate positive correlation between the duration of diabetes and the serum levels of the total cholesterol $(\mathrm{r}=0.62)$, furthermore in this study there is insignificant weak positive correlation between the serum levels of total cholesterol $(\mathrm{mg} / \mathrm{dL})$ and $\mathrm{HbA}_{1 \mathrm{c}} \%$ $(\mathrm{r}=0.32, \mathrm{P}=0.083)$.

In this study the diabetic obese patients have a significant reduction in the means of the serum levels of HDL cholesterol when compared to the control group $(\mathrm{P}=0.021)$, this result agrees with that reported by Reaven [28], who found the mean of the serum levels of HDLc was significantly lower in diabetic obese patients than in the control subjects $(\mathrm{p}=0.009)$.

The current study shows a significant reduction in the serum levels of HDL among diabetic 
patients with ischemic heart disease when compared with those without ischemic heart disease $(\mathrm{P}=0.000)$, this finding agrees with a study done by Garfagnini et al., [29] in London, who found a significant reduction of the mean of the serum level HDLc among the diabetic patients with ischemic heart disease patients.

When compared with those without ischemic heart disease $(p=0.010)$, the serum levels of HDL cholesterol of the diabetic patients with hypertension were significantly reduced when compared with those with normal blood pressure $(\mathrm{P}=0.006)$, this agrees with a study done in America by Yarone et al., [25], who reported that the mean of the serum levels of HDLc was significantly reduced among diabetic patients with hypertension when compared with those with normal blood pressure $(\mathrm{p}=0.040)$.

In addition, this study also shows a significant reduction of the means of serum levels of HDL cholesterol of the diabetic patients with renal insufficiency when compared with those with normal renal functions $(\mathrm{P}=0.010)$, this finding agrees with the results of a study done by Fabian et al., [30], who reported a significant reduction of the mean of serum levels of HDL cholesterol of the diabetic patients with renal insufficiency when compared with those with normal renal functions $(\mathrm{p}=0.015)$.

The present study shows a significant moderate negative correlation between the serum levels of HDL cholesterol $(\mathrm{mg} / \mathrm{dL})$ and the duration of diabetes $(\mathrm{r}=-0.59, \mathrm{P}=0.043)$, Pihlajamaki et al., [29] reported that hypertriglyceridemia and decreased HD cholesterol level are recognized cardiovascular risk factors.

The Canadian Heart Association [30] reported that up to half the diabetic patients type 2 have low HDL-c. Park et al., [30] observed that Low HDLc is a common lipid disorder in obesity, and this agrees with that reported by Garfagnini et al., [29], who found a significant moderate negative correlation between and the serum levels of HDL cholesterol $(\mathrm{mg} / \mathrm{dL})$ and the duration of type 2 diabetes (year) $(\mathrm{r}=0.63)$.

The present study shows insignificant weak negative correlation between the serum levels of HDL cholesterol (mg/dL) and HbA1C (\%) ( $\mathrm{r}=-0.27$, $\mathrm{P}=0.089)$, this indicates that association of obesity and diabetes are major risk factors associated with atherosclerosis.

The present study shows a significant elevation of the mean of the serum levels of LDL cholesterol of the test group when compared with the control group $(\mathrm{P}=0.013)$, this result agrees with that reported by Grundy et al., [28], who showed elevated levels of LDL, low levels of high-density lipoprotein (HDL) cholesterol, and high triglyceride levels to make up the condition known as diabetic dyslipidemia. Also the present study shows a significant elevation in serum levels of LDL cholesterol of the diabetic patients with ischemic heart disease when compared with those without ischemic heart disease $(\mathrm{P}=0.007)$, this finding agrees with that reported by Garfagnini et al., [29] in London, who found a significantly raised serum levels of LDL cholesterol of the diabetic patients with ischemic heart disease when compared with those without ischemic heart disease $(\mathrm{p}=0.030)$.

The mean serum levels of LDL cholesterol of the diabetic patients with hypertension in the current study when compared with the diabetics with normal blood pressure shows a significant elevation $(\mathrm{P}=0.000)$, this agrees with that reported by Wildman et al., [31], who found a significant elevation in the serum levels of LDL cholesterol of the diabetic patients with hypertension when compared with those without hypertension $(\mathrm{p}=0.034)$, and disagrees with the results of a study done by Yaron et al., [25] who reported that there was insignificant difference in the serum levels of LDL cholesterol of the diabetic patients with hypertension when compared with those without hypertension $(\mathrm{p}=0.0426)$.

In the present study there is significantly raised mean of the serum levels of LDL cholesterol of the diabetic patients with renal insufficiency when compared with those without renal insufficiency $(\mathrm{P}=0.015)$, this finding agrees with the results of a study done by Tomlenson et al., [33], who found a significantly raised serum levels of LDL cholesterol of the diabetic patients with renal insufficiency when compared with those without renal insufficiency $(\mathrm{p}=0.041)$.

The current study shows a significant moderate positive correlation between the serum levels of LDL cholesterol (mg/dL) and the duration of type 2 diabetes $(\mathrm{r}=0.69, \mathrm{P}=0.022)$, this agrees with that reported by Garfagnini et al., [29], who found a significant moderate positive correlation between the duration of diabetes and the serum level of LDLc $(\mathrm{p}=0.63)$. The present study also shows insignificant weak positive correlation between the serum levels of LDLc cholesterol (mg/dL) and HbA1C $(\%)(\mathrm{r}=0.32$, $\mathrm{P}=0.117$ ), this indicates that the association of obesity and diabetic are main factors for increasing the serum levels of LDLc.

The current study shows a significant elevation of the mean of the serum levels of triglycerides among the diabetic obese patients when compared to the control group $(\mathrm{P}=0.020)$, this agrees with a study done by Taskinem, who found the mean of the serum levels of triglycerides of the test group was significantly raised when compared with the control group $(\mathrm{p}=0.011)$ [32]. 
The mean of the serum levels triglycerides of the diabetic group with ischemic heart disease is significantly raised when compared with those without ischemic heart disease $(\mathrm{P}=0.016)$, this agrees with the results of a study done by Laakso et al., [33] in America, who found a significantly raised serum levels of triglycerides of diabetic patients with ischemic heart disease when compared with those without ischemic heart disease $(\mathrm{p}=0.045)$, this indicates that hypertriglycerideima may be a risk factor for atherosclerosis.

The mean of the serum levels of triglycerides of the diabetic group with hypertension is significantly raised when compared with the diabetics with normal blood pressure $(\mathrm{P}=0.000)$, this agrees with the result of a study done by Emile et al., [34], who reported a significant increase in the serum levels of triglycerides of the diabetics with hypertension disease when compared with those without hypertension $(\mathrm{p}=0.014)$, and disagrees with that reported by Yaron et al., [25], who reported insignificant difference between the mean of the serum levels of triglycerides of the diabetics with hypertension disease when compared with the diabetics without hypertension $(\mathrm{p}=0.190)$.

The present study shows a significantly raised mean of serum levels of triglycerides of the diabetics with renal insufficiency when compared with the diabetics with normal renal functions $(\mathrm{P}=0.006)$, this agrees with the results of a study done by Ruderman \& Haudenschild [35], who found a significantly raised serum levels of triglycerides of the diabetics with renal insufficiency when compared with those without renal insufficiency $(p=0.040)$. In addition, the current study shows a significant moderate positive correlation between the serum levels of triglycerides $(\mathrm{mg} / \mathrm{dL})$ and the duration of diabetes $(\mathrm{r}=0.69, \mathrm{P}=0.010)$.

The present study also shows insignificant week positive correlation between the serum levels of triglycerides and $\mathrm{HbA1C}(\%)$ as shows in (Figure 4.13) $(\mathrm{r}=0.28, \mathrm{P}=0.082)$, this indicates that diabetes and obesity are major risk factors associated with hypertriglycerideima.

The current study also showes a significant increase in the mean of the serum levels of creatinine among the diabetic - obese patients when compared to the control group $(\mathrm{P}=0.032)$, this agrees with a study done by Wannamethee et al., [36], who found that the mean of the serum levels of creatinine of the test group was significantly higher when compared with the control group $(\mathrm{p}=0.002)$.

The mean of the serum levels creatinine of the diabetic patients with ischemic heart disease is significantly raised when compared with those without ischemic heart disease $(\mathrm{P}=0.025)$, this finding is consistent with that reported by Matts et al., [37], who found a significantly raised serum levels of creatinine of the diabetics with ischemic heart disease when compared with those without ischemic heart disease $(\mathrm{p}=0.005)$.

The mean of the serum levels creatinine of the diabetic with hypertension is significantly raised when compared with those without hypertension $(\mathrm{P}=0.000)$, this agrees with the results of a study done by Shulman et al., [38], who reported a significantly raised mean of the serum levels creatinine of the diabetic patients with hypertension when compared to diabetics with normal blood pressure $(\mathrm{P}=0.007)$.

The mean of the serum levels of creatinine of the diabetics with renal insufficiency in the current study is significantly raised when compared with those with normal renal functions $(\mathrm{P}=0.000)$, this finding is consistent with that reported by Matts et al., [37], who found a significantly raised serum levels of creatinine of the diabetics with renal insufficiency when compared with those without renal insufficiency $(p=0.016)$. In addition the preset study shows a significant moderate positive correlation between the serum levels of creatinine and the duration of type 2 diabetes $(r=0.72$, $\mathrm{P}=0.000$ ), also shows insignificant weak positive correlation between the serum levels of creatinine and $\operatorname{HbA1C}(\%)(\mathrm{r}=0.35, \mathrm{P}=0.061)$, this indicates that association of diabetes and obesity have a double role in causing renal damage with deterioration of renal function.

\section{CONCLUSION}

From this study, it is concluded that; in Sudanese patients with type 2 diabetes mellitus associated with obesity: Plasma total cholesterol, LDL, and triglycerides are significantly elevated in diabetics compared to non-diabetics. Plasma HDL is negatively correlated with body mass index in diabetic patients.30\% of diabetic patients have lipid abnormalities. Serum creatinine is elevated in patient with type 2 diabetes mellitus associated with obesity. There is positive correlation between the serum creatinine and the duration of the disease.

\section{REFERENCES}

1. Wang, Y. C., Colditz, G. A., \& Kuntz, K. M. (2007). Forecasting the obesity epidemic in the aging US population. Obesity, 15(11), 2855-2865.

2. Nathan, D. M. (1993). Long-term complications of diabetes mellitus. New England journal of medicine, 328(23), 1676-1685.

3. McCance, D. R., Hanson, R. L., Pettitt, D. J., Bennett, P. H., Hadden, D. R., \& Knowler, W. C. (1997). Diagnosing diabetes mellitus-do we need new criteria?. Diabetologia, 40(3), 247-255.

4. Ruiz, J., Thillet, J., Huby, T., James, R. W., Erlich, D., Flandre, P., ... \& Passa, P. (1994). Association of elevated lipoprotein (a) levels and coronary heart disease in NIDDM patients. Relationship 
with apolipoprotein

phenotypes. Diabetologia, 37(6), 585-591.

(a)

5. Mensah, G. A., Mokdad, A. H., Ford, E., Narayan, K. V., Giles, W. H., Vinicor, F., \& Deedwania, P. C. (2004). Obesity, metabolic syndrome, and type 2 diabetes: emerging epidemics and their cardiovascular implications. Cardiology clinics, 22(4), 485-504.

6. Wild, S., Roglic, G., Green, A., Sicree, R., \& King, H. (2004). Global prevalence of diabetes: estimates for the year 2000 and projections for 2030. Diabetes care, 27(5), 1047-1053.

7. Nash, D. T. (2004). The metabolic syndrome: early clues, effective management. Consultant, 44(6), 859-865.

8. Ritz, E., \& Orth, S. R. (1999). Nephropathy in patients with type 2 diabetes mellitus. New England Journal of Medicine,341(15), 11271133.

9. Larsen, M. L., Hørder, M., \& Mogensen, E. F. (1990). Effect of long-term monitoring of glycosylated hemoglobin levels in insulindependent diabetes mellitus. New England Journal of Medicine, 323(15), 1021-1025.

10. Diabetes Control and Complications Trial Research Group. (1993). The effect of intensive treatment of diabetes on the development and progression of long-term complications in insulindependent diabetes mellitus. New England journal of medicine, 329(14), 977-986.

11. Allain, C. C., Poon, L. S., Chan, C. S., Richmond, W. F. P. C., \& Fu, P. C. (1974). Enzymatic determination of total serum cholesterol. Clinical chemistry, 20(4), 470-475.

12. Bucolo, G., \& David, H. (1973). Quantitative determination of serum triglycerides by the use of enzymes. Clinical chemistry, 19(5), 476-482.

13. Lund-Katz, S., Liu, L., Thuahnai, S. T., \& Phillips, M. C. (2003). High density lipoprotein structure. Front. Biosci, 8, d1044-d1054.

14. Nauck, M., Warnick, G. R., \& Rifai, N. (2002). Methods for measurement of LDL-cholesterol: a critical assessment of direct measurement by homogeneous assays versus calculation. Clinical chemistry, 48(2), 236-254.

15. Hall, G., Collins, A., Csemiczky, G., \& Landgren, B. M. (2002). Lipoproteins and BMI: a comparison between women during transition to menopause and regularly menstruating healthy women. Maturitas, 41(3), 177-185.

16. Garde, A. H., Hansen, А. M., Kristiansen, J., \& Knudsen, L. E. (2004). Comparison of uncertainties related to standardization of urine samples with volume and creatinine concentration. Annals of Occupational Hygiene, 48(2), 171-179.

17. Nathan, D. M., Singer, D. E., Hurxthal, K., \& Goodson, J. D. (1984). The clinical information value of the glycosylated hemoglobin assay. New England Journal of Medicine, 310(6), 341-346.
18. Rydén, L., Standl, E., Bartnik, M., Van den Berghe, G., Betteridge, J., De Boer, M. J., ... \& Priori, S. (2007). Guidelines on diabetes, prediabetes, and cardiovascular diseases: executive summary: The Task Force on Diabetes and Cardiovascular Diseases of the European Society of Cardiology (ESC) and of the European Association for the Study of Diabetes (EASD). European heart journal, 28(1), 88-136.

19. Davis, M. D., Fisher, M. R., Gangnon, R. E., Barton, F., Aiello, L. M., Chew, E. Y., ... \& Knatterud, G. L. (1998). Risk factors for high-risk proliferative diabetic retinopathy and severe visual loss: Early Treatment Diabetic Retinopathy Study Report\# 18. Investigative ophthalmology \& visual science, 39(2), 233-252.

20. Ko, G. T., Cockram, C. S., Critchley, J. A., \& Chan, J. C. (2001). Glycaemic control and obesity are the major determinants of diabetic dyslipidaemia in Hong Kong Chinese. Diabetes \& metabolism, 27(6), 637-644.

21. Georg, P., \& Ludvik, B. (2000). Lipids and diabetes. Journal of clinical and basic cardiology, 3(3), 159-162.

22. Taskinen, M. R. (1992). Quantitative and qualitative lipoprotein abnormalities in diabetes mellitus. Diabetes, 41(Supplement 2), 12-17.

23. Elbagir, M. N., Eltom, M. A., Mahadi, E. O., \& Berne, C. (1995). Pattern of long-term complications in Sudanese insulin-treated diabetic patients. Diabetes research and clinical practice, 30(1), 59-67.

24. Albrki, W. M., Elzouki, A. N., El-Mansoury, A. M., \& Tashani, O. A. (2007). Lipid profiles in Libyan type II diabetics. J Sci Appls, 1, 18-23.

25. Emile, E., WJR, J. J., \& Jane, E. R. (1993). Lipid level differences and hypertension effect in Black and Whites with type 2 Diabetes. Ethnicity Dis, 3, 242-249.

26. Ruderman, N. B., \& Haudenschild, C. (1984). Diabetes as an atherogenic factor. Progress in cardiovascular diseases, 26(5), 373-412.

27. Jones, S. L., Close, C. F., Mattock, M. B., Jarrett, R. J., Keen, H., \& Vaberti, G. C. (1989). Plasma lipid and coagulation factor concentrations in diabetic patients with microalbuminuria. BMJ; 298:487.

28. Reaven, G. M. (1987). Non-insulin-dependent diabetes mellitus, abnormal lipoprotein metabolism, and atherosclerosis. Metabolism, 36(2), 1-18.

29. Garfagnini, A., Devoto, G., Rosselli, P., Boggiano, P., \& Venturini, M. (1995). Relationship between HDL-cholesterol and apolipoprotein A1 and the severity of coronary artery disease. European heart journal, 16(4), 465-470.

30. Pihlajamäki, J., Gylling, H., Miettinen, T. A., \& Laakso, M. (2004). Insulin resistance is associated with increased cholesterol synthesis and decreased 
cholesterol absorption in normoglycemic men. Journal of Lipid Research, 45(3), 507-512.

31. O'Brien, T., Nguyen, T. T., \& Zimmerman, B. R. (1998, October). Hyperlipidemia and diabetes mellitus. In Mayo Clinic Proceedings, 73(10), 969-976.

32. Poirier, P., Giles, T. D., Bray, G. A., Hong, Y., Stern, J. S., Pi-Sunyer, F. X., \& Eckel, R. H. (2006). Obesity and cardiovascular disease: pathophysiology, evaluation, and effect of weight loss: an update of the 1997 American Heart Association Scientific Statement on Obesity and Heart Disease from the Obesity Committee of the Council on Nutrition, Physical Activity, and Metabolism. Circulation, 113(6), 898-918.

33. Wildman, R. P., Sutton-Tyrrell, K., Newman, A. B., Bostom, A., Brockwell, S., \& Kuller, L. H. (2004). Lipoprotein levels are associated with incident hypertension in older adults. Journal of the American Geriatrics Society, 52(6), 916-921.

34. Tomlinson, J. W., Owen, K. R., \& Close, C. F. (2003). Treating hypertension in diabetic nephropathy. Diabetes Care, 26(6), 1802-1805.
35. Laakso, M., Pyorala, K., Sarlund, H., \& Voutilainen, E. (1986). Lipids and lipoproteins abnormalities associated with coronary heart disease in patients with type2 diabetes mellitus. Arteriosclerosis; 6:679.

36. Wannamethee, S. G., Shaper, A. G., \& Perry, I. J. (1997). Serum creatinine concentration and risk of cardiovascular disease: a possible marker for increased risk of stroke. Stroke, 28(3), 557-563.

37. Matts, J. P., Karnegis, J. N., Campos, C. T., Fitch, L. L., Johnson, J. W., \& Buchwald, H. (1993). Serum creatinine as an independent predictor of coronary heart disease mortality in normotensive survivors of myocardial infarction. Journal of family practice, 36(5), 497-504.

38. Shulman, N. B., Ford, C. E., Hall, W. D., Blaufox, M. D., Simon, D., Langford, H. G., \& Schneider, K. A. (1989). Prognostic value of serum creatinine and effect of treatment of hypertension on renal function. Results from the hypertension detection and follow-up program. The Hypertension Detection and Follow-up Program Cooperative Group. Hypertension, 13(5_supplement), I80-I93. 